\title{
THE ACQUISITION OF TÉH AND MAH BY THE L2 LEARNERS OF SUNDANESE
}

\author{
Eri Kurniawan \\ Indonesia University of Education \\ email: erikurn@gmail.com
}

\begin{abstract}
This study examines the second language acquisition of the pragmatic particles téh and mahin L2 Sundanese by Indonesian native speakers. Two groups were compared: (i) a native control group and (ii) an advanced group of Indonesian-speaking adult L2 learners of Sundanese. A pragmatic context-matching felicitousness judgment task was employed, following Rothman (2009). A descriptive analysis and a quantitative analysis of the results were conducted, which specifically compared the performance mean score of the L2 learners to that of the native control group. A t-test was used with the alpha set at (0.05) for a 95\% confidence level. Assuming the Interface Hypothesis (Tsimpli\&Sorace, 2006; Valenzuela, 2006; Sorace, 2007, inter alia), the study presents evidence contrary to the claim that properties mediated at the syntax-pragmatic interface are more difficult to acquire than purely syntactic properties. The advanced L2 learners of Sundanese demonstrate the native-like L2 knowledge of téh and mah.
\end{abstract}

Keywords: syntax-pragmatics interface, topic and focus, second language acquisition, Indonesian, Sundanese

\section{PEMEROLEHAN TÉH DAN MAH OLEH PEMBELAJAR BAHASA SUNDA SEBAGAI BAHASA KEDUA}

\begin{abstract}
Abstrak
Penelitian ini mengungkap pemerolehan bahasa kedua terhadap partikel pragmatik téh dan mah dalam bahasa Sunda oleh penutur jati bahasa Indonesia. Penelitian melibatkan dua kelompok: (i) kelompok kontrol yang terdiri dari penutur jati bahasa Sunda dan (ii) kelompok pemelajar bahasa Sunda tingkat mahir, yang merupakan penutur jati bahasa Indonesia. Tes yang diberikan adalah tes penilaian kesesuaian konteks pragmatik, mengadopsi instrumen dari Rothman (2009). Analisis deskriptif dan kuantitatif terhadap hasil penelitian dilakukan, yang membandingkan nilai rata-rata tes kelompok pemelajar dengan kelompok kontrol. Uji-t digunakan dengan alfa (0.05) untuk tingkat keyakinan 95\%. Hasil dari penelitian ini menyanggah Hipotesis Antarmuka (Tsimpli \& Sorace, 2006; Valenzuela, 2006; Sorace, 2007) yang menyatakan bahwa fitur bahasa yang berada pada antarmuka sintaksis-pragmatik lebih sulit untuk dipelajari dibandingkan dengan fitur sintaksis saja. Penelitian ini menunjukkan bahwa pemelajar bahasa Sunda dapat menguasai penggunaan téh dan mah laiknya penutur jati bahasa Sunda.
\end{abstract}

Kata kunci: antarmuka sintaksis-pragmatik, topik dan fokus, pemerolehan bahasa kedua, bahasa Indonesia, bahasa Sunda

\section{Introduction}

An examination of recent studies on second language acquisition reveals that properties of syntax and pragmatic interface have been shown to be vulnerable (e.g. Sorace and Serratrice, 2009; Valenzuela, 2006). In particular, it has been contended by Sorace and colleagues that the syntax pragmatic interface is vulnerable for adults and subject to greater difficulty, delays, and results in residual optionality (e.g. Belleti and Leonini, 2004; Sorace, 2005, Tsimpli and Sorace, 2006; Valenzuela, 2006). 
Along the same line, Lozano (2002) argues that advanced learners' interlanguage grammars diverge from native grammars at the syntax-discourse interface with properties like focus and topic, which seem persistently problematic. The same argument has also been echoed by Sorace (2005).

The present work pursues the above line of reasoning by testing the acquisition of topic and (contrastive) focus particles, namely téh and mah respectively, in L2 Sundanese by Indonesian native speakers. The properties with L2 Sundaneseand L1 Indonesian constitute a good testing ground for the claim concerning persistently problematic acquisition of focus and topic by advanced learners (Lozano, 2002). Predictably, acquisition of formal syntactic properties in the present setting does not seem to be an issue given the fact that the syntax of the two languages under investigation is very much alike. Nonetheless, the propertiesat hand, which are mediated at the syntax pragmatic interface, must still present a learnability problem given its increased formal complexity regardless of the L1/L2 pairings (Rothman, 2009). Support for this claim comes from the L2 non-convergence with pronominal subjects in L2 Spanish noted for L1 Italian natives despite the striking resemblance of the two languages in terms of null subject properties and their pragmatic conditions (Sorace and Filiaci, 2006).

The present study contributes to the second language acquisition field by (i) testing interface properties that have been little studied in a new language pairing, (ii) providing evidence whether L2 learners exhibit the UG-constrained interlanguage grammar in terms of knowledge of topic and focus particles, and (iii) investigating which of the two particles, topic and focus, is (un)problematically acquired by L2 learners.
The present paper is organized as follows. Section 2 delineates pragmatic properties of the topic and focus particles in Sundanese. Section 3 presents the hypothesis. Section 4 describes the design and methodology. Section 5 lays out the results of the study, which will be discussed at some length in Section 6. The last section concludes the paper.

As is true of other languages such as Korean, Japanese, Chinese, and Sundanese exemplifies morphological marking, i.e. téh and mah, on a constituent in order to mark specific information status namely topic (old/given information) and focus (new information). These particles are robustly used in both oral and written language, signifying the pertinent role that they hold in the grammar of the language. Nevertheless, there has been scant linguistic literature that explicitly looks at the precise syntactic properties and pragmatic functions of these particles.

Hardjadibrata (1985) in his book "Sundanese: a syntactic analysis" makes explicit mention of téhandmahand characterizes them as markers of "emphasis" and as "phrase markers", but unfortunately, he does not offer further specificsand examples to corroborate his analysis. Likewise, Robins (1965, 1968) glosses the particles téh and téa as 'that', equating them with typical demonstratives éta and itu 'that'. Again, no evidence or argument are presented therein to warrant such treatment.

In a relatively recent work by MüllerGotama (1996), téh and mah are taken to mark a certain kind of information structure of a text. Téhis argued to be a marker of known, topical information, and maha focus marker introducing new or contrastive information. Structurally, téh and mah pattern alike in equallyadjoining to the right of any maximal constituent. In terms of distribution, as Müller-Gotama (ibid.) remarks, the two particles can generally occur in the same syntactic 
environments, as exhibited in the bold-face sentence $(1 a-b)$, where each immediately follows the same noun phrase.

(1) a. Kuring boga balad bulé. Panggih jeung manéhna nalika ulinka Bali. Manéhna téh urangAmérika.

'I have a western friend. I met him when I vacationed in Bali. He is American.'

b. Kuring boga balad bulé. Panggih jeung manéhna nalika ulinka Bali. Manéhna téh urang Rusia. Pas ulinka Jogja, kuring panggih ogé jeung bulé. Manéhna mah urang Amérika.

'I have a western friend. I met him when I vacationed in Bali. He is Russian. When I vacationed in Jogja, I met with anotherwesterner. (As for him), He is American.'

The distribution of the particles cannot be determined by merely looking at the bold-face sentence, since each particle can occur interchangeably in the same syntactic environment, as illustrated in (1a-b). One should go beyond the sentence level analysis and look at the whole discursive contexts to figure out the discourse functions of the particles. Téh occurs when the subject manéhna 'he' in (1a) refers back to the westerner the speaker met during a vacation in Bali. Thus, téh in this respect simply identifies a constituent whose reference has been evoked in earlier discourse. Conversely, mah occurs next to manéhna in (1b) to provide a contrast between the westerner the speaker met in Bali and the one he met in Jogja.

The significance of the two pragmatic particles in Sundanese is supported by Müller-Gotama's corpus study in which he found the high frequency of téh and mah, particularly in passages where a number of participants are involved. Jackson (1984 cited in Müller-Gotama, 1996) observed the same fact in Toba Batak. She concluded that focus particles have a more specialized pragmatic function than just marking unshared information. These pragmatic particles function to relate the new or unshared information to the previous text in a fairly specific way. In the context of Sundanese, the focus particle mah seems to serve corrective or contrastive functions.

The distinct pragmatic functions of the Sundanese topic and focus particle are found more obvious in the following exchange between two people conversing about Ujang, a person both interactants are familiar with or the person has been evoked in earlier discourse.

(2) a: Ujang téh nu inditka Iowa téa?

'Is Ujang the one who went to Iowa?'

b: Lain, Ujang mah nu inditka Ohio. 'No, Ujang is the one who went to Ohio.'

Ujang in (2a) is marked with téh since the referent of that person is assumed to be known or shared by both interactants. By contrast, Ujang in (2b) is marked with mah since the speaker is correcting the previous information about Ujang that the other speaker supplied.

Grammatically speaking, the use of these particles is optional. That is, their absence does not render the wellformedness of the sentence, as illustrated in (3).

(3) Manéhna urang Amérika.

'He is American.'

Manéhna in (3) is devoid of any particle, and yet the pronominal is a topic by default, assuming the crosslinguistic evidence indicating that a topic generally precedes a focus. Motivation for this assumption comes from (4) in which the topic particle téh cannot appear to the right of the otherwise new information-bearing constituent urang Amérika 'American'. The presence of the particle in such environment renders the sentence pragmatically infelicitous. 
(4) \#Manéhna urangAmérika téh.

'He is American.'

The unacceptability of (4) owes to the fact that the topic particle marks the predicate of the sentence that essentially carries new information, entailing that the subject manéhna is the topic of the sentence. The mismatch between the topic particle and the new informationbearing constituent to which the particle is attached results in pragmatic oddity. Thus, in the absence of any pragmatic particle, the subject of a sentence is construed as a topic by default. This accords with Birner\& Ward (2009) who remark that while the initial information could be topical, (discourse/hearer) old, unique, identifiable, familiar, and part of a presupposed open proposition, it is not required. This holds true of Sundanese that given/new ordering is generally the default, unless otherwise marked differently.

As noted earlier, Indonesian grammar strikingly resembles the Sundanese counterpart, since they are two closely related languages. Notice the virtually isomorphic lexical and structural mapping between the Indonesian sentence (5) and the Sundanese analogue (6).

(5) Budi membaca buku pragmatik.

'Budi read the pragmatics book.'

(6) Budi (téh/mah) maca buku pragmatik.

'Budi read the pragmatics book.'

The sole noticeable structural difference lies in the optional occurrence of téh and mah in the Sundanese structure (6). Sentence (5) conspicuously shows that Indonesian seems to be devoid of morphological means of representing the varying information-structural status that is otherwise available in Sundanese.

(7) Budi yang membaca buku pragmatik.

'It was Budi who read the pragmatics book.'

'Budi was the one who read the pragmatics book.'
In the lack of any pragmatic particle, two readings of (7) emerge. One is that Budi counts as the focalized element, sitting at the head position of a cleft clause. The other one is that Budi counts as the topicalized element, serving as the subject of an identifying clause. In fact, Indonesian has a pragmatic particle, i.e. -lah and -kah, which seems to have the corresponding function as the Sundanese mah. Like mah, the Indonesian particle gets suffixed to the right of any maximal phrase, as illustrated in the following.

(8) a. Budilah yang membaca buku pragmatik.

'It was Budi who read the pragmatics book.'

b. \#Budilah yang membaca buku pragmatik?

'It was Budi who read the pragmatics book.'

(9) a. \#Budilah yang membaca buku pragmatik?

'Was it Budi who read the pragmatics book?'

b. Budikah yang membaca buku pragmatik.'

It is apparent from (8-9) that the two particles serve the same function, namely a prototypical focus marker. Both particles target the same position in the sentence, indicating their complementary distribution. -lah can only occur in declarative sentences whereas $-k a h$ occurs only in interrogative sentences. Soemarmo (1970) claims that there is a strict parallelism between information theoretic constructs such as topic and focus and grammatical constructs like subject and predicate. He contends that in Indonesian, the subject must be the topic and the predicate must be the focus. His evidence comes from the fact that the pragmatic particles occur in sentence initial position only in cleft constructions, as signaled by the obligatory occurrence of the cleft marker yang in (8-9). When it is elided, the sentence becomes pragmatically odd, as evident in (10). 
(10) a. \#Budilah membaca buku pragmatik.

b. \#Budikah membaca buku pragmatik?

Sentences (10) are common instances of declarative sentences and the occurrence of the focus particles render the otherwise felicitous sentences infelicitous. The infelicity is ascribed to the fact that the subject, which is supposedly the topic of the sentence, is rendered to be the focus. One can predict that the focus particlescan occur to the right of the predicate, which is typically the focus of the sentence. (11) shows that this seems to be the case.

(11) Budi membaca buku pragmatikkah?

'Did Budi read the pragmatics book?'

(11) suggests that there exists a parallelism between syntactic and information structure in Indonesian. That is, the focus must occur in the predicate and the topic in the subject. This is quite unlike Sundanese, whereby the subject can function as the focus in non-cleft constructions, as seen in (6), repeated below for the convenience of the reader.

(12) Budi mah maca buku pragmatik.

In (12) the Sundanese contrastive focus particle occurs to the right of the subject and the sentence is perfectly felicitous.

An obvious question arises as to what needs to be acquired by the L2 Sundanese learners.I am assuming that téh is a morphological reflex of a pragmatic feature [topic], while mah a morphological realization of a pragmatic feature [focus]. Both features are taken to be universal and languages vary in terms of whether these features need to be morphologically realized or whether the features condition the displacement or dislocation of a certain type of constituent. The feature [topic] and [focus] have been postulated to exhibit clear-cut, transparent designated functional projections in the syntactic structure, namely TOPP and FOCP in the left periphery (Rizzi, 1997). I will follow the parallelism hypothesis (Cole, et al. 2002) that argues that the Spec, IP is a position reserved for the topic, thus correctly predicting that (10) is pragmatically ill-formed, since Budi gets focalized and therefore is banned from occupying Spec, IP.The head of IP has an uninterpretable [topic] feature that attracts the topic bearing constituent, namely the subject, to raise to Spec, IP for checking the [topic] feature.

(13)

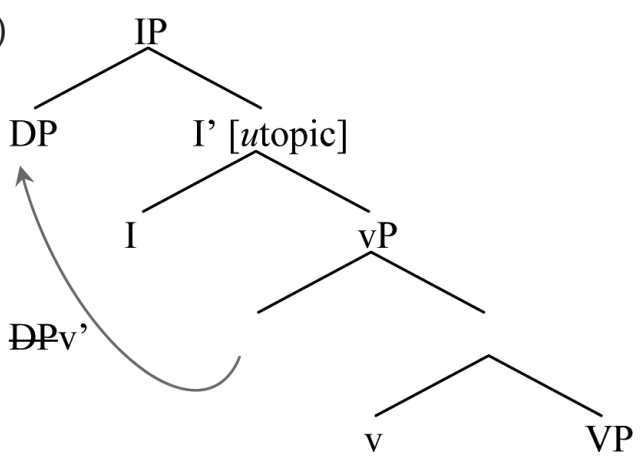

Consequently, for Indonesian speakers whose L1 grammar most closely resembles the L2 grammar but the constraints of parallelism between syntactic and pragmatic structure in the two languages are dissimilar, the acquisition task would be relatively straightforward.The L2 learners simply need to relax the strict parallelism from their L1 and learn a new pragmatic condition that subjects can be either topic or (contrastive) focus when pragmatically marked. They need to learn that Spec, IP is not exclusively reserved for harboring a [topic] feature. Instead, it can have either an uninterpretable [topic] or [focus] feature. 
(14)

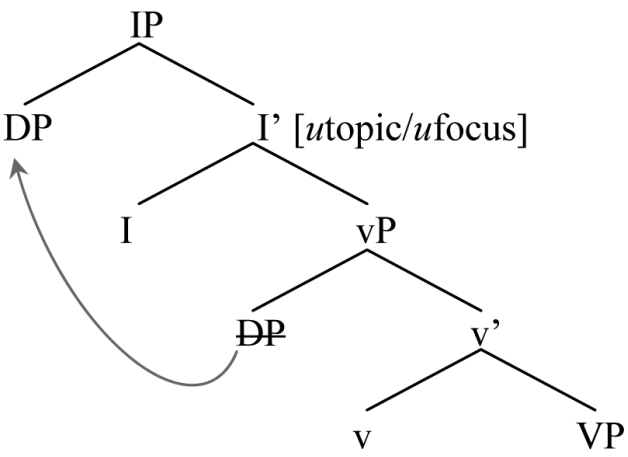

Some delays in acquiring the Sundanese pragmatic particles by the advanced L2 learners might be predicted to take place given the requirement for the L2 learners to relax the parallelism condition in L2 and the many layers of information including linguistic and nonlinguistic information that the learners need to integrate.

\section{METHOD}

By assuming the Interface Hypothesis (Tsimpli \& Sorace 2006; Valenzuela 2006; Sorace 2007 among others), the study will ascertain whether the data provide evidence in support of or against the claim that properties at the syntax-pragmatic interface are persistently problematic to acquire for adult L2 learners. A specific hypothesis is formulated as follows.

- Syntax-discourse: Advanced learners of Sundanese will demonstrate convergent knowledge of theSundanese pragmatic particles, but they will demonstrate inevitable vulnerability with the knowledge of the particles.

This section describes the design and methodology of the present study. Two groups are compared: (i) a native control group and (ii) an advanced group of Indonesian-speaking adult L2 learners of Sundanese. Data from the experiment are provided, which test the pragmatic knowledge of Sundanese pragmatic particles.

The experimental group consisted of native speakers of Indonesian $(\mathrm{n}=8)$, almost all of who have been residing in Sundanese speaking area for periods of varying length. They were recruited through personal acquaintances on the Facebook and the yahoo mailing list. Almost all of them are language teachers at schools and were students at an Indonesian university in Bandung, a Sundanese speaking region in Indonesia. The age range was 22-30 (mean=27.25). The participants had learned Sundanese in either a formal setting through schools or an informal one through daily interaction with native speakers. Many of these participants are apparently near-natives. However, since there was no independent screening procedure to justify this, they were referred to as advanced learners. There was also a control group of Sundanese native speakers $(n=9)$, who were recruited through the Facebook as well. They have a variety of professions and the age range was 22-42 (mean=29).

A pragmatic context-matching felicitousness judgment task was employed, following Rothman (2009). It was designed to test for L2 knowledge of pragmatic conditions that govern the distribution of the topic and focus particles. The task asked the participants to judge on a 1-5 Likert rating scale on the degree of acceptability of the sentences with respect to the given contexts. Crucially, each of these sentences is perfectly grammatical in isolation. Thus, the sole difference lies in how well each sentence fits the specified context. 1 was defined as completely unacceptable and 5 completely acceptable. There were four different types of sentences ( $\mathrm{n}=4$ each type), as exemplified in (15).

(15) a. Context supports téh Siti dan Imas sedang membicarakan kehebatan Asep, teman sekolah mereka yang selalu menjadi bintang kelas tiap semester. Siti berkata ....

Siti and Imas are talking about Asep, their schoolmate who 
always ranks top in the class every semester. Siti says ....

Asep téh pinter-pinter teuing, nya? 12345

Asep is very smart, right?

b. Context does not support téh

Wawan sedang menceritakan kepada Yanti bahwa Dedi punya mobil Ferrari. Karena

Dedi tetangganya Yanti, Yanti sangat tahu bahwa mobilnya Dedi itumobil Jaguar. Yanti berkata ....

Wawan is telling Yanti that Dedi owns a Ferrari car. Since Dedi is her neighbor, Yanti knows very well that Dedi's car is Jaguar. Yanti says ....

Mobilna Dédi téh mobil Jaguar. 12345 Dedi's car is Jaguar

c. Context supports mah

Wawan sedang menjelaskan di dalam kelas bahwa ibukota Amerika itu New York. Yanti, salah satu murid Wawan yang cerdas dalam pengetahuan dunia tahu bahwa ibukota Amerika seharusnya Washington DC. Yanti berkata ....

Wawan is lecturing in a class that the capital of the United States is New York. Yanti, one of Wawan's students who is good at the world knowledge, knows that the capital is Washington DC. Yanti says ....

Ibukota Amerika mah Washington DC, Pa. 12345

Sir, the capital of the United States is Washington DC.

d. Context does not support mah Yanti berbisik kepada temannya bahwa dia tidak menyukai orang yang berbicara di depannya. Dia berkata bahwa bahasa Sunda orang tersebut sangat kasar. Yanti berkata....

Yanti is whispering to her friend that she detests the person talking in front of her. She said that his register of Sundanese is so coarse. Yanti says ...

Basa Sunda na mah manika sarpisan, nya? 12345

His Sundanese is very coarse, right?

It should be noted that the contexts were given in Indonesian so that the vocabulary was not a confounder. Contexts like (15a and 15c) depicted contexts that indicate topic maintenance and corrective focus, and therefore necessitate the use of téh and mah, respectively. Judgments on these kinds of sentences should have been on the acceptable side of the scale. On the other hand, contexts like (15b and $15 \mathrm{~d})$ presented a mismatch between what the contexts pragmatically required and the kind of marker in the accompanying sentence. Thus, judgments on these sentences should have been on the unacceptable side of the scale.

\section{RESULTS}

This section is divided into two subparts: (i) a descriptive analysis of the results and (ii) a quantitative analysis, which specifically compares the mean performance score of the L2 learners against that of the native controls. As is standard, a t-test was used with the alpha set at (0.05) for a 95\% confidence level.

\section{Descriptive Analysis}

As can be seen in Figure 1 below, the L2 learners generally perform remarkably native-like. Strikingly, the learners somewhat outperform the native controls in their rating of téh and mahunder felicitous circumstances. In the rating of sentences with infelicitous téh and mah, however, the judgments of which should have been lower, the L2 learners rated such sentences slightly higher than the native controls. 
Results of Felicitousness Judgment Task

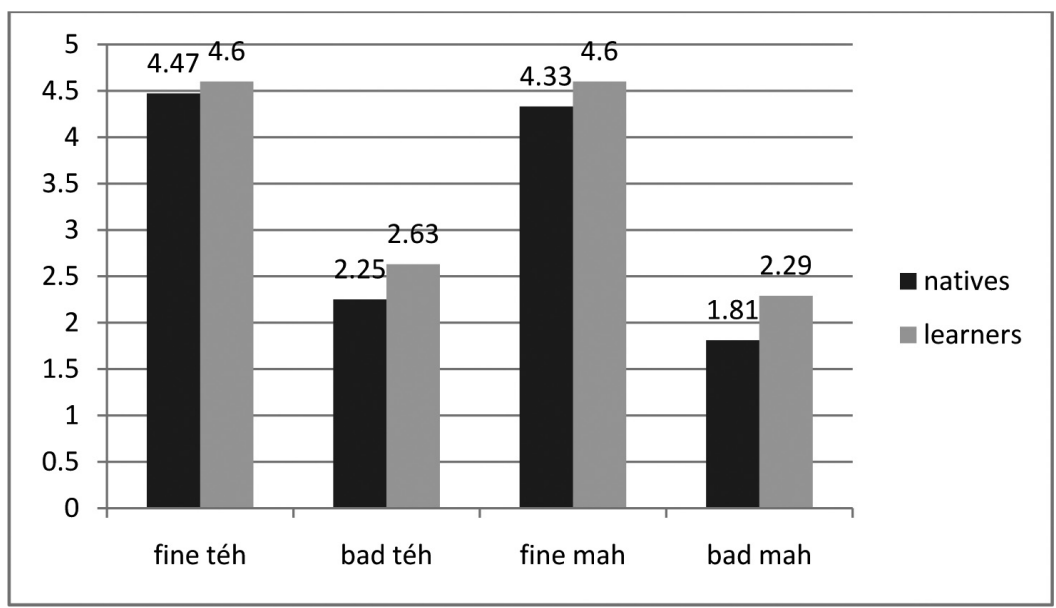

Figure 1. Results of felicitousness judgment task. Fine téh and fine mah represent the contexts that pragmatically require téh and mah, respectively. Meanwhile, bad téh and bad mah represent the contexts that do not warrant téh and mah, respectively.

Intergroup comparisons were made for each context by comparing the performance of the learners against that of the natives. Unsurprisingly, both groups perform as expected. They accept the occurrence of téh and mah in the sentences under the contexts that warrant the given particle. Conversely, they reject the sentences in which téh and mah do not pragmatically match the given contexts.

\section{Statistical Analysis}

At-test was used to quantify the group data in order to ascertain if there is a significant statistical difference between the L2 learners' performance and the native controls' performance. Statistical analysis of all contexts revealed no significant differences in the L2 learners' versus the natives' performance: fine téh $(\mathrm{p}=0.35)$, bad téh $(\mathrm{p}=0.23)$, fine mah $(\mathrm{p}=0.16)$ and bad mah $(\mathrm{p}=0.16)$.

\section{Discussion of Results}

In this section, the data from the experimental task are summarized and discussed in terms of what they indicate about the L2 Sundanese knowledge of the pragmatic particles and how this has implications to current L2 acquisition theories.

It is apparent from the previous section that the results of the present study clearly demonstrate that the L2 learners converge on interface-conditioned properties, in which case the L2 learners performed almost exactly native-like. They even performed slightly better than the native controls at rating the sentences with felicitous téh and mah. This native-like L2 knowledge demonstrates that the L2 learners have successfully acquired the pragmatic conditions that regulate the use of téh and mah. Or, differently put, these learners have already learned that the spec of IP in the L2 grammar could be filled by a topic or focus bearing subject.

These results provide evidence contra the Interface Hypothesis, according to which the syntax-pragmatics interface is inevitably vulnerable (e.g. Sorace and Serratrice, 2009; Valenzuela, 2006) and persistently problematic for adult L2 learners (Lozano, 2002). The data from this study suggest that at advanced levels syntax-pragmatics interface-conditioned 
properties can be completely acquired and residual optionality or vulnerability does not always take place at all L2 interface phenomena, in accord with Iverson and Rothman (2008). This finding is not novel, as Ivanov (2009), for instance, in his study on the acquisition of L2 Bulgarian clitics, convincingly shows that the properties mediated at the syntax-pragmatics interface are apparently acquirable. The same kind of conclusion can also be found in Rothman's (2009) study on L2 Spanish pronominal subjects that concludes that the syntax-pragmatics interface is not an inevitable locus of fossilization (in contra Valenzuela, 2006).

Since the present study only reports the data from the advanced learners who happened to have acquired the properties in question at the time of testing, it is difficult to address the issue of whether development stages or levels of proficiency play a role in this respect. Further research by involving learners of different levels of proficiency is hence required to arrive at a more conclusive answer to such a question.Screening measures or tests will also be a vital part of future research to warrant the claim that the learners are at the level they are claimed to be.

Another potential flaw of the design of this study is the lack of production data, written or spoken. The constraints of time and financial resources to solicit such dataare two primary reasons behind the absence of production data in this study. In the future, one could elicit production data through story telling scenario, picture identification task, or even a corpus study like the one carried out by Lozano and Mendikoetxea (2007).

\section{Conclusion}

The present study tested the interpretive properties of the two particles in L2 Sundanese, i.e. téh and mah, and provides evidence in support to recent research findings (Ivanov, 2009, Rothman,
2009) that interface-conditioned properties are acquirable and do not necessarily lead to residual optionality. It has been shown that the L2 learners of Sundanese have successfully acquired the pragmatic conditions that govern the use of the two particles. These learners have been able to relax the parallelism constraint from their L1 and learned that Spec, IP is not exclusively reserved for the topical subject. More importantly, the results of this study go against Lozano's (2002) claim that advanced learners' interlanguage grammars diverge from native grammars at the syntax-discourse interface with properties like focus and topic, which seems persistently problematic.

\section{References}

Belleti, A., \& Leonini, C. 2004. "Subjecti Inversion in L2 Italian". EUROSLA Yearbook, 4.95-118.

Birner, B., J. \& Ward, G. 2009. "Information Structure and Syntactic Structure". Language and Linguistics Compass 3/4, 1167-1187.

Cole, P., Hermon, G., Inoha, K., \&Tjung Y. 2002." A Constraint on Wh in Situ in Javanese". MIT Working Papers in Linguistics, 44.107-102.

Hardjadibrata, R. R. 1985. Sundanese: a Syntactical Analysis. Canberra: Australian National University, Department of Linguistics.

Ivanov, I. 2009. "Second Language Acquisition of Bulgarian Object Clitics: a Test Case for the Interface Hypothesis". Doctoral Dissertation, University of Iowa.

Iverson, M., \& Rothman, J. 2008."The Syntax-Semantics Interface in L2 Acquisition: Genericity and Inflected Infinitive Complements in Nonnative Portuguese". In Garavito, J. B., \& Valenzuela, E. (eds.), Selected Proceedings of the $10^{\text {th }}$ Hispanic Linguistics Symposium, 78-92. Sommerville, M.A.: Cascadilla Proceedings Project. 
Lozano, C. 2002. “The Interpretation of Overt and Null Pronouns in Nonnative Spanish".Durham Working Papers in Linguistics, 8.53-66.

Lozano, C., \& Mendicoetxea. 2007. "Interface Conditions on Postverbal Subjects: a Corpus Study of L2 English". Corpus Linguistics.

Müller-Gotama, F. 1996. "Topic and Focus in Sundanese". Anthropological Linguistics, 38.117-132.

Rizzi, L. 1997."The Fine Structure of the Left Periphery". In L. Haegeman (ed.), Elements of Grammar. Kluwer: Dordrecht.

Robins, R. H. 1965. “Some Typological Observations on Sundanese Morphology". Lingua, 15.435-450.

Robins, R. H. 1968. "Basic Sentence Structures in Sundanese". Lingua, 21. 351-358.

Rothman, J. 2009. “Pragmatic Deficits with Syntactic Consequences?: L2 Pronominal Subjects and the SyntaxPragmatic Interface". Journal of Pragmatic, 41.951-973.

Soemarmo. 1970. "Subject-Predicate, Focus-Presupposition, and TopicComment in Bahasa Indonesia and Javanese".Doctoral dissertation, UCLA.

Sorace, A. 2005. "Selective Optionality in Language Development". In Cornips,
L. and Corrigan, K.P. (eds) 2005. Syntax and Variation. Reconciling the Biological and the Social, 55-80. Amsterdam: John Benjamins.

Sorace, A. \& Filiaci, F. 2006. "Anaphora Resolution in Near-Native Speakers of Italian". Second Language Research, 22.339-368.

Sorace, A. 2007. "Optionality at the SyntaxDiscourse Interface in Near-Native L2 Speakers".Second Language6.3-16.

Sorace, A. \& Serratrice. 2009. "Internal and External Interfaces in Bilingual Language Development: Beyond Structural Overlap". International Journal of Bilingualism, 13.195-210.

Tsimpli, I.M., \&Sorace, A. 2006. "Differentiating Interfaces: L2 Performance in Syntax Semantics and Syntax Discourse Phenomena". In D. Bamman, T. Magnitskaia, and C. Zaller (eds.), Proceedings of the 30th annual Boston University Conference on Language Development, BUCLD 30, 653664. Somerville: Cascadilla Press.

Valenzuela, E. 2006."L2end StateGrammars and Incomplete Acquisition of Spanish CLLD Constructions. InR. Slabakova, S. Montrul and P. Prevost, (eds.), Inquiries in Linguistic Development: In Honor of Lydia White, 283-304. Amsterdam: Johns Benjamins. 